\title{
Assessment of voluntary counselling and testing (vct) service quality in terms of client satisfaction; a comparative study between public and private health institutions in Addis Ababa, Ethiopia
}

\author{
Fasika Dinku ${ }^{1}$, Gashaw Andargie ${ }^{2}$ \\ ${ }^{1}$ Johns Hopkins University- TSEHAI, Addis Ababa, Ethiopia \\ ${ }^{2}$ College of Medicine and health sciences, University of Gondar, Gondar, Ethiopia
}

Email address:

fasikadinku@gmail.com (F. Dinku),gashawab@yahoo.com (G. Andargie)

\section{To cite this article:}

Fasika Dinku, Gashaw Andargie. Assessment of Voluntary Counseling and Testing (VCT) Service Quality in Terms of Client Satisfaction; a Comparative Study between Public and Private Health Institutions in Addis Ababa, Ethiopia. Science Journal of Clinical Medicine. Vol. 2, No. 1, 2013, pp. 1-7. doi: 10.11648/j.sjcm.20130201.11

\begin{abstract}
Background: Although Quality of the service is key principle for effectiveness of the program, very little work has been done to assess the quality of Voluntary Counseling and Testing (VCT) services in most countries including Ethiopian. Objectives: To assess quality of VCT services in terms of client satisfaction in both private and public VCT sites. Methods: cross-sectional comparative health institution based study was employed in public and private VCT sites in Addis Ababa from January 1 to February 30, 2009. By modifying the UNAIDS VCT Quality Evaluation Tools and quality assurance and quality improvement guide developed by Family Health International (FHI), data were collected using interviewer administered questionnaires for both qualitative and quantitative methods. Results: A total of 160 clients, of which 80 from private and 80 from public as well as 20 counselors of which seven from private and 13 from public sites were included in the study. Clients from public sites were more satisfied than private sites with the VCT service they took; $90 \%$ versus $76 \%$. Motivation of seeking the service, estimated time spent waiting the test result and waiting to see the counselor, service fee, the presence of comfortable and private counseling room, service given individually, issue of confidentiality, discussion with counselors on different risks and meaning of the test result had significant difference in public and private institutions. Educational status of grade 9-12 in private sites $\mathrm{OR}=.22(.05-.92), \mathrm{p}=.038$, time spent on waiting the test result within $30-60$ minutes in public sites OR=8.4(1.5-41.9), $\mathrm{p}=.024$, information on HIV/AIDS and Sexual transmitted Infections (STIs) given to protect themselves and others in private sites $\mathrm{OR}=62.3(17.7-123), \mathrm{p}=.025$, counselor comfortable on taking sensitive issue in private sites $(\mathrm{OR}=54.5(2.3-90.1), \mathrm{p}=.014)$ were found to be significantly associated with client satisfaction. All, but one, counselor took training in formal institutions, all counselors from public and only some in private were given fulltime counseling, no regular supportive supervision by governmental officials or partners, all had not taken any refreshment training. Conclusions and recommendations: generally, rate of client satisfaction was low in private VCT sites so that effort should be made to maintain the quality. In addition, regular and supportive supervision by regional health bureau and its partners were minimal so that strong and coordinated supervision in both sites need to be done.
\end{abstract}

Keywords: Voluntary Conesling and Testing (VCT), Client Satisfaction, Public and Private Sites

\section{Introduction}

Voluntary Counseling and Testing (VCT) is an entry point for prevention and care and is acknowledged internationally as an effective strategy for both HIV/AIDS prevention and care. Researchers have provided strong evidence that VCT is an effective and cost-effective strategy for facilitating be- havior change. It is one of the key strategies that Ethiopia is implementing for prevention and control of the pandemic since 1996 from the first VCT guideline published (1, 2, 3).

As the HIV epidemic continues spread throughout developing countries of the World, the quality and effectiveness of interventions designed to reduce transmission are very critical. Quality involves the consistent delivery of a product or service according to expected standards $(4,5)$. 
Improved access to high-quality HIV counseling and rapid testing services, in a variety of settings, responded to a large unmet need; the resulting increase client satisfaction so that uptake of these services was dramatic - up to 13-fold in South Africa and 6-fold in Lilongwe. In the health care system of Ethiopia, even though emphasis was given to increase coverage, quality of service is now an issue and become one of the components of health sector development program and also quality management frame work for HIV/AIDS service is developed $(6,7)$.

Quality and nature of strategic information relating to the pandemic and the effects of our programmes, Governments and international donors are trying to strengthening their technical and financial support to improve quality and coverage of VCT services. In counseling--perhaps more than in any other area of service provision--service quality determines the outcome. Poor quality counseling can result in misunderstanding and even resistance to change (8) .

Although Quality of the service is key principle for effectiveness of the program, very little work has been done to assess the quality of VCT services in most countries including Ethiopian (5).

\section{Methods and Materials}

A cross- sectional comparative institution based study was carried out from November to December 2008 in Addis Ababa, which is found in the heart land of Ethiopia with the population of 2.7 million. All clients and counselors in Addis Ababa were source population; clients, aging greater than 18 years, who undertaken counseling and counselors who were currently doing counseling during day of data collection on selected sites were study population.

The sample size was determined by using two population proportion sampling method; client satisfaction on public VCT sites in similar study is $95 \%$ but no similar study was found on private sites so that it was assumed that the difference between the two VCT sites would be $15 \%$; using $95 \%$ CI, $80 \%$ power and $10 \%$ non- response rate, a total 160 clients from both sides were included in the exit interview. Systematic sampling method was used to select study subjects. For qualitative study 20 counselors purposively selected from both sites were included.

Using UNAIDS VCT Quality Evaluation Tools and quality assurance and quality improvement guide developed by FHI/ USAID, data were collected by interviewer administered questionnaires for both qualitative and quantitative methods.

Data were entered and analyzed using SPSS version 15; frequency of different variables were calculated, the association between dependent and independent variable were analyzed by using Odds Ratio and confounding were controlled by using logistic regression.

The study was conducted after approval of ethical review Committee from University of Gondar and Addis Ababa health bureau as well as written consent from study subjects. Confidentiality of the study population was maintained.

\section{Results}

A total of 160 clients were included during the exit interview, of which 80 were from public and the remaining 80 were from private health institution. Response rate was $100 \%$.

\subsection{Socio- Demographic Characteristics of Respondents}

The socio- demographic characteristics of the respondents are shown in table 1. Comparisons were done between public and private institutions; there were no significant differences on socio- demographic characteristics between them. A little over half $43(53.7 \%)$ of respondents from public and 44 (55\%) from private were females.

Table 1. Socio- demographic characteristics of VCT clients in Addis Ababa, Ethiopia, February, 2009.

\begin{tabular}{|c|c|c|c|c|}
\hline Characteristics & $\begin{array}{l}\text { Public } \\
\text { Frequency } \\
(\%)\end{array}$ & $\begin{array}{l}\text { Private } \\
\text { Frequency } \\
(\%)\end{array}$ & $\mathbf{X}^{2}$ & $\begin{array}{l}\text { Significance } \\
\text { P-Value }\end{array}$ \\
\hline \multicolumn{5}{|l|}{ Sex } \\
\hline Male & $37(46.3)$ & $36(45)$ & & \\
\hline Female & $43(53.7)$ & $44(55)$ & 1.07 & .785 \\
\hline \multicolumn{5}{|l|}{ Age(yrs) } \\
\hline $15-24$ & $32(40.0)$ & $36(45.1)$ & & \\
\hline $25-34$ & $35(43.8)$ & $39(48.8)$ & .03 & .874 \\
\hline $35+$ & $13(16.3)$ & $5(6.3)$ & & \\
\hline \multicolumn{5}{|l|}{ Marital status } \\
\hline Single & $53(66.3)$ & $55(68.8)$ & & \\
\hline Married & $16(20)$ & $17(21.3)$ & 1.62 & .655 \\
\hline Divorced & $5(6.3)$ & $5(6.3)$ & & \\
\hline Widowed & $6(7.5)$ & $3(3.8)$ & & \\
\hline $\begin{array}{l}\text { Educational } \\
\text { status } \\
\text { Illiterate } \\
1-8 \\
9-12 \\
\text { college }\end{array}$ & $\begin{array}{l}7(8.8) \\
18(22.6) \\
28(35) \\
27(33.8)\end{array}$ & $\begin{array}{l}5(6.3) \\
13(16.3) \\
33(41.3) \\
29(36.3)\end{array}$ & 4.01 & .135 \\
\hline
\end{tabular}

The majority of clients were between the age group of 25-34 years, $35(43.8 \%)$ in the public verses $39(48.8 \%)$ in the private; followed by $15-24$ years which were $32(40 \%)$ versus $36(45 \%)$ with a median age of $26 \pm 7.2$ years and $25 \pm$ 6.2 years of public and private sites respectively.

Concerning marital status, 53 (66.3\%) verses 54 (67.5\%) were single followed by married, counting $17(21.3 \%)$ and $16(20 \%)$ in the public and private institution respectively. Respondents' educational status on grade 9 and above was, $55(68.8 \%)$ from public while $62(77.6 \%)$. Clients with level of education 9-12 grade from private VCT sites were less satisfied than clients having college education level. $(\mathrm{OR}=.22$, CI.05, .92).

\subsection{Setting of VCT Sites}

There was significant difference between private and public institutions $(\mathrm{P}<0.05)$ on the time spent to receive the test result.

Fifty eight (72.5\%) from public against $69(86.4 \%)$ from private clients spent $30-60$ minutes waiting to see their 
counselors. Similarly $63(78.8 \%)$ clients from public versus $41(51.3 \%)$ clients from private received their test result within 30-60 minutes. Clients from public sites spent 30-60 minutes had 8 times more satisfied than those clients who spent more than an hour waiting to receive their test result (OR 7.8, CI 1.5, 41.9) (table 3). While the majority of clients $55(68.8 \%)$ in both sites responded that they estimated less than 30 minutes spent during counseling.

Table 3. setting of VCT service in public and private institution in Addis Ababa, February, 2009.

\begin{tabular}{|c|c|c|c|c|c|c|c|c|}
\hline \multirow{2}{*}{ characteristic } & \multicolumn{8}{|c|}{ client satisfaction } \\
\hline & \multicolumn{3}{|c|}{ public } & \multicolumn{3}{|c|}{ private } & & \multirow[b]{2}{*}{ AOR } \\
\hline & yes & No & COR & AOR & Yes & No & COR & \\
\hline \multicolumn{9}{|c|}{$\begin{array}{l}\text { Time spent waiting } \\
\text { the result }\end{array}$} \\
\hline$<30$ minutes & 6 & 0 & $\mathrm{~N} / \mathrm{A}$ & \multirow{3}{*}{$7.8(1.5,41.9)^{*}$} & 9 & 0 & \multirow{3}{*}{$\begin{array}{l}\mathrm{N} / \mathrm{A} \\
.54(.18,1.64) \\
1\end{array}$} & \multirow{3}{*}{$\begin{array}{l}.54(.17,1.77) \\
1\end{array}$} \\
\hline 30-59 min. & 59 & 4 & $8.4(1.7,41.4)^{*}$ & & 28 & 13 & & \\
\hline$>60$ minutes & 7 & 4 & 1 & & 24 & 6 & & \\
\hline \multicolumn{9}{|c|}{$\begin{array}{l}\text { Time spent waiting } \\
\text { to see the counselor }\end{array}$} \\
\hline$<30$ minutes & 54 & 4 & $2.7(.25,29.0)$ & $1.1(.07,14.8)$ & 51 & 18 & \multirow{3}{*}{$\begin{array}{l}\text { N/A } \\
\text { N/A }\end{array}$} & \\
\hline 30-59 min. & 13 & 3 & $.87(.07,10.4)$ & $1.9(.1,32.9)$ & 19 & 1 & & \\
\hline$>60$ minutes & 5 & 1 & 1 & 1 & 1 & 0 & & \\
\hline \multicolumn{9}{|c|}{$\begin{array}{l}\text { Time spent } \\
\text { during session }\end{array}$} \\
\hline $\begin{array}{l}<30 \text { minutes } \\
30-59 \text { min. }\end{array}$ & $\begin{array}{l}48 \\
24\end{array}$ & $\begin{array}{l}7 \\
1\end{array}$ & $\begin{array}{l}.29(.33,2.5) \\
1\end{array}$ & $.5(.05,4.96)$ & $\begin{array}{l}39 \\
22\end{array}$ & $\begin{array}{l}16 \\
3\end{array}$ & $.28(.34,2.4)$ & $.41(.1,1.7)$ \\
\hline \multicolumn{9}{|c|}{$\begin{array}{l}\text { Counseling } \\
\text { room private } \\
\& \text { comfortable }\end{array}$} \\
\hline Yes & 71 & 8 & \multirow{2}{*}{ N/A } & & 43 & 13 & $1.1(.36,3.4)$ & $.64(.75, .22)$ \\
\hline no & 1 & 0 & & & 18 & 6 & 1 & 1 \\
\hline
\end{tabular}

There was a significant difference on the presence of private and comfortable VCT room $(\mathrm{P}<0.001)$. Almost all (98.8\%) of clients public sites versus $70 \%$ of clients from private sites responded that the VCT rooms were private and comfortable.

Seventy five $(93.6 \%)$ verses 63 (78.8\%) of clients thought that the confidentiality would be ensured. This also has a marked difference between the two groups $(\mathrm{P}<0.05)$. Twenty seven $(34 \%)$ of clients from public sites perceived confidentiality insured by using codes followed by assurance by the counselors, 23 (28.8\%). Whereas $42(52.5 \%)$ of clients from private were perceived counselors assurance would insure confidentiality followed by use of codes which was $20(25 \%)$.

\subsection{Counseling Process}

Sixty nine (86.3\%) respondents from public and $64(80 \%)$ respondents from private responded that they had discussed on different risks and when these risks appeared.

In addition $49(61.3 \%)$ of clients from public sites, 52 $(65 \%)$ of clients from private responded that they had taken information to protect themselves and other from HIV/AIDS respectively; this had an association with client satisfaction in private sites that is clients who have got information were 
63 times more satisfied than who didn't. (OR 62.3, CI 17.7, sample size is small. (Table 4).

123). The confidence interval is very wide because the

Table 4. Counseling process in relation to client satisfaction in public and private institutions in Addis Ababa, February, 2009.

\begin{tabular}{|c|c|c|c|c|c|c|c|c|}
\hline \multirow{3}{*}{ variable $s$} & \multicolumn{8}{|c|}{ client satisfaction } \\
\hline & \multicolumn{4}{|c|}{ public } & \multicolumn{4}{|c|}{ private } \\
\hline & yes & No & $\mathrm{COR}$ & AOR & Yes & No & $\mathrm{COR}$ & AOR \\
\hline \multicolumn{9}{|l|}{$\begin{array}{l}\text { Information given } \\
\text { to protect } \\
\text { from HIV/STIs }\end{array}$} \\
\hline & 49 & 0 & N/A & & 45 & 4 & $30.9(16.7,144)^{*}$ & $5.8(.39,84.8)$ \\
\hline Yes some no & 17 & 5 & $1.7(.31,9.37)$ & & 12 & 4 & $8.3(1.7,41.25)^{*}$ & $62(17.7,123)^{*}$ \\
\hline & 6 & 3 & 1 & & 4 & 11 & 1 & 1 \\
\hline \multicolumn{9}{|l|}{$\begin{array}{l}\text { Clients comfortable } \\
\text { on asking questions }\end{array}$} \\
\hline & 65 & 4 & $2.3(.23,23.8)$ & & 57 & 6 & $19(2.9,36.3)^{*}$ & $2.2(.6,76.9)$ \\
\hline Yes some no & 0 & 3 & N/A & & 2 & 9 & $6(.93,38.6)$ & $.05(.01,2.8)$ \\
\hline & 7 & 1 & 1 & & 2 & 4 & 1 & 1 \\
\hline \multicolumn{9}{|c|}{$\begin{array}{l}\text { Counselor comfortable } \\
\text { on talking } \\
\text { sensitive issues }\end{array}$} \\
\hline $\begin{array}{l}\text { Yes Had } \\
\text { some discomfort no }\end{array}$ & $\begin{array}{l}56 \\
9 \\
7\end{array}$ & $\begin{array}{l}2 \\
3 \\
3\end{array}$ & $\begin{array}{l}12(1.7,47.7)^{*} \\
1.3(.2,8.43) \\
1\end{array}$ & & $\begin{array}{l}51 \\
8 \\
2\end{array}$ & $\begin{array}{l}4 \\
6 \\
9\end{array}$ & $\begin{array}{l}57.4(9.1-86.1)^{*} \\
.167(.03,1.07) \\
1\end{array}$ & $\begin{array}{l}55(2.3,90.1)^{*} \\
7.1(.33,51.7) \\
1\end{array}$ \\
\hline \multicolumn{9}{|l|}{$\begin{array}{l}\text { Counselors } \\
\text { discussed on } \\
\text { different sex types }\end{array}$} \\
\hline Yes Some No & $\begin{array}{l}15 \\
10 \\
47\end{array}$ & $\begin{array}{l}0 \\
0 \\
8\end{array}$ & N/A & & $\begin{array}{l}7 \\
14 \\
40\end{array}$ & $\begin{array}{l}3 \\
1 \\
15\end{array}$ & $\begin{array}{l}.88(.2,3.8) \\
5.3(.6,43.5) \\
1\end{array}$ & $\begin{array}{l}17.7(.1,29.14 .) \\
.08(.001,6.15) \\
1\end{array}$ \\
\hline $\begin{array}{l}\text { Discussed with } \\
\text { different risks } \\
\text { Yes Some No }\end{array}$ & $\begin{array}{l}63 \\
1 \\
8\end{array}$ & $\begin{array}{l}6 \\
1 \\
1\end{array}$ & $\begin{array}{l}1.3(.14,12.34) \\
.13(.004,4.0) \\
1\end{array}$ & & $\begin{array}{l}54 \\
5 \\
2\end{array}$ & $\begin{array}{l}10 \\
5 \\
4\end{array}$ & $\begin{array}{l}10(1.74,27.1)^{*} \\
2(.24,16.4) \\
1\end{array}$ & $\begin{array}{l}2.2(.7,71.4) \\
20.5(.18,91) \\
1\end{array}$ \\
\hline $\begin{array}{l}\text { Explained } \\
\text { about window } \\
\text { period } \\
\text { Yes Some No }\end{array}$ & $\begin{array}{l}62 \\
3 \\
7\end{array}$ & $\begin{array}{l}5 \\
2 \\
1\end{array}$ & $\begin{array}{l}1.8(.2,17.4) \\
.21(.1,3.4) \\
1\end{array}$ & & $\begin{array}{l}52 \\
3 \\
6\end{array}$ & $\begin{array}{l}15 \\
1 \\
3\end{array}$ & $\begin{array}{l}1.7(.39,7.8) \\
1.5(.11,21.3) \\
1\end{array}$ & $\begin{array}{l}07(.001,4.8) \\
2.9(.02,487.5) \\
1\end{array}$ \\
\hline $\begin{array}{l}\text { Meaning of the } \\
\text { HIV test result } \\
\text { Yes No }\end{array}$ & $\begin{array}{l}67 \\
5\end{array}$ & $\begin{array}{l}6 \\
2\end{array}$ & $\begin{array}{l}4.5(.71,28.1) \\
1\end{array}$ & & $\begin{array}{l}60 \\
1\end{array}$ & $\begin{array}{l}19 \\
0\end{array}$ & N/A & N/A \\
\hline \multicolumn{9}{|l|}{$\begin{array}{l}\text { Discussed on } \\
\text { strategies on } \\
\text { partner notification }\end{array}$} \\
\hline $\begin{array}{l}\text { Yes } \\
\text { No }\end{array}$ & $\begin{array}{l}42 \\
30\end{array}$ & $\begin{array}{l}1 \\
7\end{array}$ & $\begin{array}{l}9.8(1.15,83.9)^{* *} \\
1\end{array}$ & & $\begin{array}{l}44 \\
17\end{array}$ & $\begin{array}{l}4 \\
15\end{array}$ & $9.7(\mathbf{2 . 8 , 3 3 . 4}) * *$ & $\begin{array}{l}10.4(.89,121.3) \\
1\end{array}$ \\
\hline $\begin{array}{l}\text { Do you refer } \\
\text { your relatives to } \\
\text { take the service } \\
\text { Yes } \\
\text { no }\end{array}$ & $\begin{array}{l}67 \\
5\end{array}$ & $\begin{array}{l}5 \\
3\end{array}$ & $\begin{array}{l}\mathbf{8}(1.5,43.8)^{*} \\
1\end{array}$ & & $\begin{array}{l}58 \\
3\end{array}$ & $\begin{array}{l}16 \\
3\end{array}$ & $\begin{array}{l}3.6(.67,19.7) \\
1\end{array}$ & $\begin{array}{l}1.9(.4,97.6) \\
1\end{array}$ \\
\hline $\begin{array}{l}\text { do you } \\
\text { think } \\
\text { confidentiality ensur }\end{array}$ & & & & & & & & \\
\hline $\begin{array}{l}\text { yes } \\
\text { no }\end{array}$ & $\begin{array}{l}67 \\
7\end{array}$ & $\begin{array}{l}8 \\
0\end{array}$ & N/A & & $\begin{array}{l}54 \\
7\end{array}$ & $\begin{array}{l}9 \\
10\end{array}$ & $\begin{array}{l}\text { 8.6(2.6,28.4)** } \\
1\end{array}$ & $\begin{array}{l}2.6(.24,28.2) \\
1\end{array}$ \\
\hline
\end{tabular}

Similarly $69(86.3 \%)$ of client from public and $63(78.8 \%)$ of clients from private had felt comfortable on asking counselors questions that they couldn't understood.

Fifty eight (72.5\%) clients from public and $53(66.3 \%)$ clients from private clinic responded that counselors were comfortable on taking with sensitive issues. There was a significant association with client satisfaction for counselors who were comfortable to discuss about sensitive issues in 
private sites, that is clients were 55 times more satisfied when the counselors, who were comfortable on handling sensitive issues, OR (54.5 CI 2.3, 90.1).

Fifty five $(68.8 \%)$ clients from both public and private responded they had not given information on different types of sex. While Seventy three $(91.3 \%)$ of client from public and $78(97.5 \%)$ of clients from private have been told and understood the meaning of the test result.

\subsection{Client Satisfaction and other Characteristics}

Sixty seven (83.8\%) of clients from public and $66(82.5 \%)$ of clients from private didn't wish to be counseled by other counselors; whereas $13(16.2 \%)$ verses 18 (17.5\%) wished to be counseled by other counselors. Counselors having the same sex and similar age group with clients and counselors who are more concerned on counseling were some of the reasons listed why clients' needs to be counseled by other counselors.
More than half of the respondents 44 (55\%) from public sites didn't take the service before, whereas more than half $41(51.3 \%)$ of clients from private sites took the service before.

There was significant difference between public and privates VCT sites in terms of client satisfaction $(\mathrm{P}<0.05)$. Sixty nine (90\%) of clients from public versus 61 (76.3\%) of clients from private were satisfied with the service they took. Majority of respondents in both public and private were comfortable on recommending their relatives to take the service $72(90 \%)$ and $74(92.5 \%)$ respectively.

\subsection{Counselors' Interview}

Twenty counselors were interviewed during the study period. In each VCT sites the number of counselors reached 5-10 in public and 1-6 in private institutions. All counselors interviewed during the study period were nurses.

Table 2. Socio-demographic characteristics in relation to client satisfaction in public and private institution in Addis Ababa, February, 2009.

\begin{tabular}{|c|c|c|c|c|c|c|c|c|}
\hline \multirow{3}{*}{ variable s } & \multicolumn{8}{|c|}{ client satisfaction } \\
\hline & \multicolumn{4}{|c|}{ public } & \multicolumn{4}{|c|}{ private } \\
\hline & yes & No & COR & AOR & Yes & No & COR & AOR \\
\hline $\begin{array}{l}\text { Sex } \\
\text { Male } \\
\text { Female }\end{array}$ & $\begin{array}{l}31 \\
41\end{array}$ & $\begin{array}{l}6 \\
2\end{array}$ & $\begin{array}{l}25(.041,1.34) \\
1\end{array}$ & $27(.04,1.81)$ & $\begin{array}{l}28 \\
33\end{array}$ & $\begin{array}{l}8 \\
11\end{array}$ & $\begin{array}{l}1.2(.41,3.30) \\
1\end{array}$ & $\begin{array}{l}71(.19,2.55) \\
1\end{array}$ \\
\hline $\begin{array}{l}\text { Age(yrs) } \\
15-24 \\
25-34 \\
35+\end{array}$ & $\begin{array}{l}29 \\
31 \\
12\end{array}$ & $\begin{array}{l}3 \\
4 \\
1\end{array}$ & $\begin{array}{l}81(.08,8.54) \\
.65(.07,6.4) \\
1\end{array}$ & $\begin{array}{l}39(.02,8.6) \\
.55(.03,9.1) \\
1\end{array}$ & $\begin{array}{l}24 \\
33 \\
4\end{array}$ & $\begin{array}{l}12 \\
6 \\
1\end{array}$ & $\begin{array}{l}2.0(.201,19.914) \\
.727(.069,7.684) \\
1\end{array}$ & $\begin{array}{l}28(.02,3.9) \\
99(.75,13.2) \\
1\end{array}$ \\
\hline $\begin{array}{l}\text { Marital status } \\
\text { Single } \\
\text { Married } \\
\text { Divorced } \\
\text { Widowed }\end{array}$ & $\begin{array}{l}49 \\
14 \\
5 \\
4\end{array}$ & $\begin{array}{l}4 \\
2 \\
0 \\
2\end{array}$ & $\begin{array}{l}6.13(.85,44.36) \\
3.5(.37,33.31) \\
\text { N/A } \\
1\end{array}$ & $\begin{array}{l}16.4(.99,270) \\
3.1(.16,58.3) \\
\text { N/A }\end{array}$ & $\begin{array}{l}44 \\
12 \\
3 \\
2\end{array}$ & $\begin{array}{l}11 \\
5 \\
2 \\
1\end{array}$ & $\begin{array}{l}2(.17,24.12) \\
1.2(.09,16.44) \\
.75(.04,14.97) \\
1\end{array}$ & $\begin{array}{l}1.8(.13,24.5) \\
1.1(.07,17.4) \\
.25(.01,6.8) \\
1\end{array}$ \\
\hline $\begin{array}{l}\text { Educational status } \\
\text { Illiterate } \\
1-8 \\
9-12 \\
\text { college }\end{array}$ & $\begin{array}{l}7 \\
17 \\
23 \\
25\end{array}$ & $\begin{array}{l}0 \\
1 \\
5 \\
2\end{array}$ & $\begin{array}{l}\text { N/A } \\
1.4(.11,16.2) \\
.37(.07,2.09) \\
1\end{array}$ & $\begin{array}{l}\text { N/A } \\
.688(.03,15) \\
1\end{array}$ & $\begin{array}{l}5 \\
10 \\
20 \\
26\end{array}$ & $\begin{array}{l}0 \\
3 \\
13 \\
3\end{array}$ & $\begin{array}{l}\text { N/A } \\
.39(.07,2.23) \\
.18(.04, .71)^{*} \\
1\end{array}$ & $\begin{array}{l}\mathrm{N} / \mathrm{A} \\
.79(.09,6.68) \\
.022(.05, .92)^{*} \\
1\end{array}$ \\
\hline
\end{tabular}

\subsection{Counseling Training}

All except one counselor from both sites had taken formal VCT training, which took more than ten days. And counselors rated the training was adequate.

Female counselor from private site responded that:

"I didn't take counseling from formal training center but I had taken what it is from my nursing course and now I am assigned to VCT clinic to provide counseling".

No counselor took refreshment training from both groups. One male nurse counselor from private site responded.

"I have taken counseling training 10 years before and still I am providing counseling but I didn't get refreshment training since my first formal training. You know providing counseling for a long time will expose to develop burn out syndrome; despite this responsible bodies doesn't give attention".

Majority of counselors wished if they had training on ART,
PMTCT, and HIV testing which would help them during counseling session to provide enough information to their clients.

\subsection{VCT Service Setting}

All counselors were assigned as fulltime in counseling room in the public institutions while most private site counselors were expected to give the service in addition with other works in the clinic. The average time spend on counseling by private counselors were less than 4 hours per day.

The average number of clients that a counselor counseled per day was 10 at public sites and 8 at private sites. These numbers might increase or decrease depends on the client flow; one female counselor from private site explained:

"It depends on the flow the client, sometimes I might not counsel a client, in other way the clients flow might go more than 20 so I am supposed to counsel them; despite the VCT protocol limits the number.". 
Respondent's list ways of maintaining confidentiality: assuring of clients, using private counseling room, using code rather than registering their name.

Female counselor from public site explains:

"When clients come to me I do not ask their names rather I use code then I will assure them, that anything we talk should be private which will not discussed with any one else unless clients do so, during the introduction to the orientation to the session."

Respondents from public sites explained that the majority of test result of the client will reach within 30-59 minutes. While some counselors from private answered the result will reach less than 30 minutes and some answered greater than an hour.

Most counselors have pressurized by the reaction of clients during counseling process.

\subsection{One Female Counselor from Public Sites Explained}

"Counseling is hearing the problem of the clients especially how and when they contract risky behaviors which will make you pressurized. Unless you know yourself awareness and externalize it, you will develop burnout".

\subsection{Supervision by Higher Bodies}

The majority of counselors in both sites responded that supportive and regular supervision was minimal.

Counselors list and explained some of the factors that affect the quality of counseling that need to be considered: the counseling process itself, basic and refreshment training for the counselors, monitoring and supervision by higher officials, trying to cover multiple tasks at once, fee of the service, issue of confidentiality, counselors' performance and clients' motivation of seeking the service. Male respondent from private explained:

"The counseling process should be revised, average the time allocated at each protocol doesn't take that much amount of time, clients do not want to stay long in counseling “.

\section{Discussion}

Level of client satisfaction on VCT service in this study was $90 \%$ in public while $76 \%$ in private institutions. This showed that there was a significant difference between the two groups. The reason could be counselors in private institution might be busy at multi task activities so that enough time on counseling might not be given.

The level of satisfaction of the public VCT sites was little lower than the study done in Zambia 96\% and Vietnam 95\%. While the satisfaction level of client from private institution was much lower than that of Zambia and Vietnam studies; the reason could be due to shortening of long waiting time, improving the capacity of counselors through basic and refresher training $(6,9)$.

The study demonstrated that socio-demographic characteristics of both public and private had no significant dif- ference. Nearly $70 \%$ and $80 \%$ of clients from public and private respectively had educational status more than secondary, this implies majority of clients were educated. Moreover the logistic regression analysis indicated that grade 9-12 in private institution had less satisfied than clients' having college education level ( $\mathrm{OR}=.22$, CI .05, .92); the possible reason could be clients having college education level would freely discuss on HIV/AIDS risks with their counselor and able to ask questions that they couldn't understand during the counseling process.

The study revealed that $87 \%$ of client from public and $62 \%$ from private clients test result given within the same hour and the rest clients in both group were taken their result within same day. There was significant association between waiting time of the test result between 30-60 minutes and client satisfaction in public institution, that is clients who spent 30-60 minutes had 8 times more satisfied than clients who spent more than an hour, which implies that clients didn't want to spent long time waiting there result; so that clients who could receive their test result and posttest counseling increased. This finding is congruent with the study done in India that satisfaction was increased because of VCT sites significantly decreased long waiting time. While research done in government VCT sites in Kenya showed only $82 \%$ of the clients test result given within the same day $(7,10)$.

In the current study, information given to clients to protect themselves and others from HIV/ AIDS and other STIs had no statistically difference in public and private institutions, but the study found that client satisfaction had strong association $(\mathrm{P}<0.05)$ with the information given in private VCT sites, that is clients were 63 times more satisfied when information given during counseling session than those who didn't give; the reason could be, counselors might think that clients coming to seek the service have necessary information on HIV/AIDS, counselors might have busy on multiple tasks so that they tried to shorten counseling process or it could be due to lack of up to date information. However studies in South Africa showed that $100 \%$ and $90 \%$ of clients were given information on HIV/AIDS and other STIs by nurse counselors and lay counselors respectively. This showed that both public and private VCT site counselors, who are nurses, didn't give information to their clients than lay counselors in South Africa (11).

There was no statistically difference between public and private VCT sites on counselors' performance of talking with sensitive issue with clients. But there was strong association with client satisfaction at private VCT sites. That is clients were satisfied when the counselors were comfortable with talking sensitive issues. This could be due to the fact that most clients came here to know their HIV status because of their perceived risky behavior and these behaviors are sensitive and needed to be discussed well.

According to the HCT guideline counseling is given by counselors who are trained on counseling from formal institutions. In this study except one counselor who didn't take the formal counseling training, all have trained at least for 10 
days; this would increase the quality of counseling given. But in a study done in South Africa only $41 \%$ of the counselor had formal training and similar finding seen in Malawi $(11,12)$.

The present study shows that counselors from private VCT sites were congested with multiple tasks other than counseling. This is because private need to gain profit at each step of their work so; counselors are not allowed to sit in VCT room waiting clients, rather they have to be given different tasks so that clinics can minimize and effectively use of human resources.

Supportive supervision ensures the quality of the VCT service but Lack of regular supportive supervision was seen in both groups of the study this could be due to minimal supervisor to support all VCT sites in the city regularly as well as the partners organization might be reluctant to support the activity. The findings was similar with the study done in Malawi (12).

\section{Conclusion}

Educational status in private sites, time spent on waiting the test result, information on HIV/AIDS and STIs given to protect them and others in private sites, counselor comfortable on taking sensitive issue in private sites were found to be significantly associated with client satisfaction. All counselors from public and only some in private were given fulltime counseling, no regular supportive supervision by governmental officials or partners, all had not taken any refreshment training.

Generally, client satisfaction was higher in public than private sites.

\section{References}

[1] MOH/FHAPCO. Single point HIV prevalence estimate, Addis Ababa, MOH/FHAPCO, 2007.
[2] MOH/FHAPCO.HCT guideline of Ethiopia. MOH/FHAPCO, 2007.

[3] FHAPCO. Annual HIV/AIDS monitoring and evaluation report, Addis Ababa, FHAPCO, 2006/2007.

[4] Campbell S, Roland M.O, Buetow S.A. defining quality of care: Social Science and Medicine. 2000;51:1611-1625.

[5] FHI/IMPACT. Evaluating programs for HIV/AIDS prevention and care in developing countries: a handbook for program managers and decision makers, FHI/IMPACT. 2001.

[6] Pronyk PM, Kim JC, Makhubele MB, Hargreaves JR, Mohlala R, Hausler HP. Introduction of voluntary counseling and rapid testing for HIV in rural South Africa: from theory to practice. AIDS Care. 2002.14(6):859-65.

[7] Bwanali H Jereni and Adamson S Muula. Availability of supplies and motivations for accessing voluntary HIV counseling and testing services in Blantyre, Malawi. BMC Health Serv Research. 2008; 8: 17.

[8] Carolina population center, measure evaluation-Voluntary counseling and testing, university of North Carolina, 2000.

[9] KAPC. C O Rachier, E Gikundi, D H Balmer, M Robson, K F Hunt, $\mathrm{N}$ Cohen The meaning and challenge of voluntary counseling and testing (VCT) for counselors - report of the Kenya Association of Professional Counselors (KAPC) conference for sub-Saharan Africa. Journal des Aspects Sociaux du VIH/SIDA. 2004.1 (3).

[10] WHO. Report of a "Lessons Learnt" Workshop on the Six Pro-TEST Pilot Projects in Malawi, South Africa and Zambia (Durban, South Africa, 3-6 February 2003. WHO. 2004.

[11] V. Solomon, H. Van Rooyen, R. Griesel, D. Gray, J. Stein and V. Nott. Critical Review and Analysis of Voluntary Counseling and Testing Literature in Africa. Health system trust/ university of Kwasulu-Natal, 2004.

[12] Tran, Dat T; Hoang, Thai N; Nguyen, Hong T; Nguyen, Thang T; Luu, Minh N;Kamb, Mary L; Luu, Chau M; Do, Nguyet T;Do, Giang H; Wolfe, Mitchell I. Client Survey of Voluntary HIV Counseling and Testing (VCT) in Vietnam: An Alternative Means of Evaluating Service Quality. CDC, Atlanta, 2004. 